University of Rhode Island

DigitalCommons@URI

Open Access Master's Theses

1960

\title{
A Comparison of Acceptance Attitude of a Selected Group of Teachers and Counselors
}

Donald Herman Anderson

University of Rhode Island

Follow this and additional works at: https://digitalcommons.uri.edu/theses

\section{Recommended Citation}

Anderson, Donald Herman, "A Comparison of Acceptance Attitude of a Selected Group of Teachers and Counselors" (1960). Open Access Master's Theses. Paper 1162.

https://digitalcommons.uri.edu/theses/1162

This Thesis is brought to you for free and open access by DigitalCommons@URI. It has been accepted for inclusion in Open Access Master's Theses by an authorized administrator of DigitalCommons@URI. For more information, please contact digitalcommons-group@uri.edu. 
THESIS COLL

371.422

An 23

A COMPARISON OF ACCEPTANCE ATTITUDES OF A SRLECTED

GROUP OF TEACHERS AND COUNSELORS

BY

DONALD HERMAN ANDERSON

A THESIS SUBMITTED IN PARTIAL FULFILLMENT OF THE

REQUIREMENTS FOR THE DEGREE OF

MASTER OF SCIENCE

IN

EDUCATION

UNIVERSITY OF RHODE ISLAND

1960 


\section{MASTER OF SCIENCE THESIS}

\section{OF}

DONALD HERMAN ANDERSON

Approved:

Major Professor:
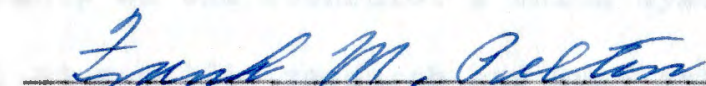

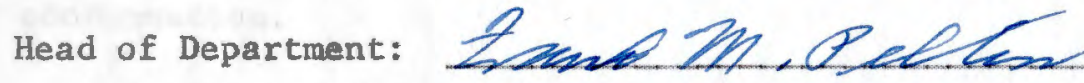

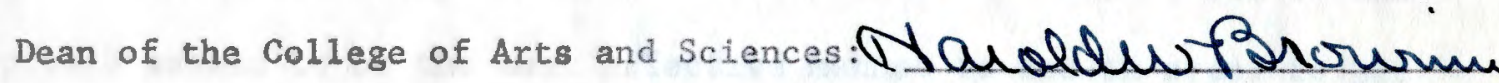
Director of Graduate studies: 4 ane 3 
ABSTRACT

The purpose of this study was to investigate the possibility that professional guidance counselors were less likely than professional teachers to condem students in counseling situations. This contention was based upon past experiences and personal observations that indicated that teachers were more apt to use condemnation than counselors as a technique to change student behavior in an individual counseling situation. This problem was related to the value system of the professional person. A survey of the literature revealed some exploration in the general area of the relationship of the counselor's value system to the counseling situation. However, no specific research had been attempted in the area of condemation.

An interview type study was attempted in this area, since this approach seemed to be the most effective method to use in order to get beyond the surface of the problem. The research instrument that was developed for this study consisted of a case problem, fifteen questions designed to elicit interviewee responses, and an information questionnaire to provide additional relevant background information. After a pilot study had been completed some minor modifications were made in the research instrument.

In keeping with the methods employed, a subjective evaluation rather than a statistical analysis was used in interpreting the results of the study. The responses of the interviewees, subjective in nature, suggested the following inferences: 
1. Both teachers and counselors appeared to be sensitive to the authority image of the school administration.

2. Teachers generally reacted in an authoritarian manner and counselors usually reacted in an understanding role.

3. The counselors were less likely than the teachers to consider the boy in the problem situation lacking in moral fiber and character.

4. Guidance counselors appeared less ego protective than did the teachers during the interviews.

5. The differences in attitudes exhibited by teachers and counselors during the interviewe may be partially explained by their respective personality makeups and the type of training that each role requires for certification. 


\section{ACKNOWLEDGEMENTS}

The writer wishes to express his sincere appreciation and gratitude to Dr. Frank M. Pelton, Dr. S. Marvin Rife, Dr. Charles R. Dolan, and Dr. L. Guy Brown for their thoughtful advice and assistance in writing this thesis. Their constant, considered help and inspiration have made it a pleasure to carxy out this phase of my graduate work.

Donald H. Anderson 
ABSTRACT. . . . . . . . . . . . . . . . . . . . . 111 ACKNOWLEDGEMRTS. . . . . . . . . . . . . . . . . . . . v LIST OF TABLES. . . . . . . . . . . . . . . . . . . . . vil CHAPTERS

I. STATEMENT OF THE PROBLEM .................. . . 1

II. SURVEY OF THE LITERATURE. . . . . . . . . . . . . 8

III. THE PROCESS OF INVESTIGATION . . . . . . . . . . . 12

IV. THE RESULTS OF THE STUDY . . . . . . . . . . . . 18

V. CONCLUSIONS AND RECOMMNDATIONS. . . . . . . . . . . 28 APPENDIXES

A. THE CASE STUdY INSTRUMENT. . . . . . . . . . . . . 31

B. THE INTERVIEW QUESTIONS. . . . . . . . . . . . . 32

C. THE INFORMATION QUESTIONNAIRE. . . . . . . . . . . . 33 BIBLIOGRAPHY. . . . . . . . . . . . . . . 34 


\section{LIST OF TABLES}

Table

1. Sex, Religious Affiliation, Present Educational Level, and Marital Status of the Teachers and Counselors

Used in the Study............................. 19 
CHAPTER I

STATEMENT OF THE PROBLEM

Professional guidance counselors and teachers are both involved in counseling situations with students. It appears to be a well understood concept that the attitudes held by teachers and counselors toward their students can greatly affect the meaningfulness of the experience for the students involved. If the professional person's relationship with the student in a conflict situation is one of basic understanding one might expect positive help accruing to the student. However, if the feelings exhibited by the professional person are condemnatory in nature one might expect unsatisfactory results to take place in the frame of reference of the student. This theory, the attitude of acceptance and understanding, appears to hold true whether the situation is one of counseling or a group teaching activity:

A nagging, moralizing atmosphere brings out negative responses in students. It pricks their consciences without giving them any way to change or any help in learning better behavior. Too f dequently the ideals upheld and the attitudes expressed by teachers are compatible with students' theoretical values, but incompatible with the practical life they live.1

The purpose of this study is to investigate the possibility that professional guidance counselors are less likely to condemn a student in a given situation than would be true of a professional teacher. This

IWilliam G. Morse and G. Max Wingo, Psychology and Teaching (New York: Scott, Foresman and Company, 1955), p. 294. 
contention is based upon past experiences and personal observations that Indicate that teachers as a group and individually are more apt to use condemnation as a technique to change student behavior in an individual counseling situation than would be true of guidance counselors confronted with the same case.

This problem is related to the value system of the professional person or the counselee. There are many points of view regarding values. A philosopher may consider that values are absolute truths. A religious leader may call them a moral code. An economist may give the term a monetary connotation. An educator may think of values as an aid to student motivation. The public in general seems to be concerned with values. One rarely considers any experience unless it is in terms of right and wrong or good and bad.

In searching for the meaning of values the following two definitions seem to explain the term in a satisfactory manner:

The value of a thing is its worth or desirability as compared with something else. Values cluster around (1) activities and attitudes which serve needs of the group, or a large or dominant portion of the group, or (2) about ways of life which have become habitual or customary and therefore require little conscious adjustment from day to day, or they are (3) so intertwined with other elements in the culture that disturbance of one part of the complex threatens others.1

Cultural values define ways of action or belief that are important to a society's sense of identity. For example, Americans value churchgoing, public education, and equal justice under law. These values define our "way of 1 ife," and a great deal of energy and resources are expended to promote and defend them. ${ }^{2}$

IJohn L. Gillin and John P. Gillin, An Introduction to Sociology (New York: The Macmillan Company, 1946), p. 141.

${ }^{2}$ Leonard Broom and Philip Selznick, Sociology: A Text with Alapted Readings (White Plains, New York: Row, Peterson and Company, 55), P. 29. 
Since the values of a culture are developed in the individual by the process of learning, they seem to be of a relative nature rather than an absolute or eternal element. A value system is developed within an individual through the interaction of hereditary and environmental factors.

At birth, inherited characteristics are not something definite, but rather are unrealized potentials. They do not demand a particular type of behavior:

Heredity is potential and dynamic but it is undefined activity before it reaches a life organization. It has no organized character apart from environment, apart from experience. Isolated from these it remains only a composite of undefined potentialities. 1

This organic heritage interacts with a social environment. Bach aperience that an individual has changes his personality in some way. As the biological potential interacts with society, human nature develops within the individual.

Human beings appear to be born without any sense of right and wrong. Behavior specialists claim that there is no instinct of conscience:

This view is confirmed by the great variation in strength and the severity of conscience among human beings. Certain people appear to be completely without conscience. Unless they are watched by a policeman, they obey every impulse toward theft, cruelty, and deceit. Yet they know that these things are judged to be wrong by society, and that they will be punished if they are caught. other people are conscience ridden. If they make some minor mistake, such as being rude to a friend or forgetting to return a book they have borrowed, they suffer the torments of the damned. Unless we are prepared to make the highly improbable assumption that we inherit differences in conscience, much as we inherit eye-color, we must agree that conscience depends upon the experience of a person. 2

1L. Guy Brown, Sociel Pathology: Persenal and Seclal Disorganization (New York: F. S. Crofts and Company, 1946), p. 25.

${ }^{2} W$. Allison Davis and Robert J. Havighurst, Father of the Man: Tour Child Gets His Personality (Boston: Houghton Mifflin Company, 7), p. 170 . 
Human beings are amoral at birth. There is almost no kind of behavior which is judged wrong by one group that is not judged right by another. In some societies eating human flesh is approved behavior. One's particular type of behavior develops through the interaction of a hereditary potential with the experiences provided by an environment. The result is human nature:

Insanity is just as much human nature as sanity. Delinquency is human nature, as are likewise the behavior patterns of the law-abiding citizen. Dishonesty must be classed with honesty as human nature. Sex pathologies of all types are human nature along with sex normalities. Lying and veracity are human nature. Any adjustment is human nature, whether it is socially approved or disapproved. Degradation on the lowest known level is human nature quite as much as manifestations that are called noble and sublime.1

Change in the human nature of an individual is a continuous process, gometimes influenced through planned counseling experiences. Such pxperiences work in the direction of enabling the insane to become sane, the delinquent to become nondelinquent, the dishonest to become honest, the unmotivated to become motivated, and the confused to become organized. These modifications in behavior take place as new situations are experienced. A value system develops within an individual in much the same way that any other form of behavior expresses itself in the life organization of the individual. It appears to be behavior that is learned as a result of the interaction of the hereditary potentials with environmental experiences.

As a value system develops in an individual so does a value system develop in a teacher and a counselor. Certain feelings of condemation may exist within a value system. Since feelings of condennation are merely a part of the person's larger value system it is but another step to the 
realization that the specific part is probably developed in much the same way as any other section of the entire system. These collective sections make up the entire value system.

There seems to be a relative readiness of the individual to condem and be condemed. The foundations of control are found in the primary training of the individual. His conformity to a standard is developed in terms of an expected role. Another person's conduct becomes the model for his own. Punishment and reward are the beginning inciters to conformity, but in time the individual internalizes his contacts with others and develops a conscience.

As has been mentioned before, the attitudes held by teachers and counselors can have either positive or negative effects on the students they interact with. Most experts seem to believe that condemnation is a negative way to treat a behavior or discipline problem.

Landis mentions:

The more modern society has shifted from punishment to guidance in home, $8 \mathrm{chool}$ and state the more effective discipline has become. Our studies of teenagers show that the greatest loyalty and respect for parents' views in contemporary society is found, not in authoritarian families, but in democratic ones. The more the school has shifted toward guidance and away from a regime of the hickory stick, the greater the loyalty of children and young people to the school program and the more effective the school has become in motivating young people toward learning. 1

Fenton carries this philosophy even further:

From the point of view of mental hygiene, all persons who deal with children should avoid an attitude of condemnation and feelings of disapproval or resentment. 2

1Paul H. Landis, Social Control: Social Organization and Disorganiation in Process (New York: J. B. Lippincott Company, 1956), p. 444.

2Norman Fenton, Mental Hygiene in Scheol Practice (Stanford, Cal1fornia: Stanford University Press, 1948), P. 132. 
Anderson believes that: "for those who really aren't interested in truth or reality, there still remains the culturally honored motivation power of virtue and the deterring force of guilt, the dogmatic concepts of right and wrong."I She makes an even stronger statement in this respect: "Guilt and virtue -.- they are both so stupid and so unnecessary and so unrealistic." 2

If it is true that the attitude of condemnation can negatively effect the student to a greater or lesser degree, it would appear logical that professional people dealing with students in the midst of a highly intimate situation should be aware of the effect their own values have on the counselee. The counselor or teacher might tend to feel more secure in the counseling situation if he has some understanding in dealing with questions of value. Above all, the counselor or teacher should not subject the counselee to possible emotional damage by an unwarranted use of his own value system in the counseling process.

It appears that the professional person may not be able to keep his value system entirely out of the counseling situation because the results of counseling have value to the teacher or counselor. When the professional person uses his value system in a counseling situation it can be a very subtle experience, unrecognizable to the interviewer or interviewee. This study may point up the fact that the more training an individual has had in counseling techniques the more clever he is at covering up his own value system during the counseling process.

1Camilla M. Anderson, Saints, Sinners, and Psychiatry (Philadelphia: J. B. Lippincott Company, 1950), p. 189. 2 Ibid., 183. 
Very little has been done to investigate the relationship of the teacher's or counselor's value system to the counseling situation. This study is an attempt to examine this slightly charted area and to develop and add to the body of knowledge in this field.

Finally, this study may have implications on the selection and training of future counselors and teachers. It is probable that many people who enter and remain in teaching do so because of an intense need to dominate individuals. The school society seems to offer the teacher ample backing for this type of behavior. 


\section{CHAPTER II}

\section{SURVEY OF THE LITERATURE}

This study was developed to explore and find out whether fessionally certified teachers are more likely to condem a student in a counseling situation than professionally certified guidance counselors. There have been some studies in this general area but no previous study, to the knowledge of the writer, has been made on this specific problem.

Some counselors like Rogers, Tolbert, and Patterson, imply that the counselor should try to maintain a non-evaluative atmosphere when dealing with the counselee. However, other counselors, including Williamson, Warters, and Mathewson, appear on the other end of the continuum and feel that counselors should teach values to the client while in the counseling situation. The process of making moral judgments while in the counseling situation is definitely a minority opinion, however. Most authors in the fields of counseling, soclology, psychiatry, and psychology seem to feel that the behavior of the client is goal oriented, that is, directed toward meeting his felt needs. They seen to be in general agreement that the individual is a product at least partly of his past experiences and how he perceives them. Rogers states: Behavior is basically the goal-directed attempt of the organism to satisfy its needs as experienced, in the field as perceived." I

${ }^{2}$ Carl R. Rogers, Client-Centered Therapy (New York: Houghton Ufflin Company, 1951), p. 491. 
Five pertinent pieces of literature that have had a significant bearing on this thesis have been prepared by Rosenthal, Biestek, Williamson, Erickson, and Patterson. Other studies, though they relate indirectly, have not been included here because they do not deal centrally with the problem of this thesis.

The value system of the counselor may effect the counselee in dramatic ways. Rosenthall believes that "the values of the counselor show up in the counseling situation," and directly influence the directions taken by the client. He studied twelve clients presenting a wide variety of diagnosis, ranging in age from eighteen to forty-six, who had from three weeks to one year of psychotherapy. Early in the therapy they were given a test of moral values, along with other tests. The counselors, who were psychiatric residents, were also given similar tests. The clients repeated the test at the conclusion of treatrnent. It was assumed that the therapist's values were stable and they did not repeat the test. It was found that, in general, clients' scores on the moral values test changed during therapy, with those patients rated as improved becoming more like their therapists, while those rated as unimproved tended to become less like their therapists.

Biestek, 2 in considering the non-judgmental attitude of the counselor, mentions that he does not "relinquish his own sense of values," for he must maintain the integrity of his own personality. He goes on to explain that the counselor does not become moralistic, but that he does have a right to

1David Rosenthal, "Changes in Some Moral Values Following Psychotherapy," Journal of Consulting Psychology, Vol. 19 (December, 1955), 431436.

2F. P. Biestek, "The Non-Judgmental Attitude," Social Casework, XXXIV (June, 1953), 235-239. 
his own sense of moral values.

Williamson tends to make the counselor an authority or expert

flgure. He defines counseling as:

- a peculiar type of relatively short-term human relationship between a 'mentor' with some considerable experience in problems of human development, on the one hand, and a learner, on the other hand, who faces certain clearly or dimly perceived difficulties in his efforts to achieve self-controlled or selfanipulated forward-moving development. 1

He appears to be against maintaining a value neutrality in ralation to the client. Williamson feels that a counselor should teach his moral system or some other to the client so he can freely choose from the alternatives. There seems to be some emphasis here to have the counselor accept the teacher's methods for use in the counseling situation.

Erickson, 2 in his unpublished doctoral dissertation, has examined the social characteristics of counselors. He feels that the counselor's value system is not changed to any great degree by his professional training, but that this training does enable the counselor to more cleverly cover up his own value system in the counseling situation. Professional guidance counselors may be more clever at hiding their real feelings than teachers would be under a similar situation, according to Erickson. 3

The most comprehensive work to date on the value system of the counselor within the counseling situation has been done by Patterson in his text Counseling and Psychotherapy: Theory and Practice, where he devotes

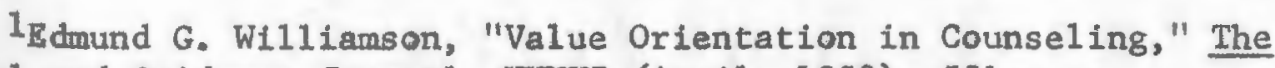
pennel and Guidance Journal, XXXVI (April, 1958), 521.

2A1lan C. Erickson, "An Investigation of the Relationship of Social Characteristics to Responses from Selected Michigan High School "unselors" (unpublished Ed. D. dissertation, School of Graduate Studies, "ichigan State College), p. 107.

3interview with Dr. Allan C. Erickson, Professor of Education, University of Bridgeport, Connecticut, February 12, 1960. 
a chapter to this vital area. Most counseling textbooks do not mention this aspect of the counseling process, but rather infer that the counselor ohould be as non-judgmental as possible for the situation he is dealing with.

Patterson thinks that the counselor will feel more secure in the counseling situation if he has some foundation in dealing with questions of value. He also believes that the counselor will not subject the counselee to emotional damage by an unwarranted use of his value system in the counseling process, if he is aware of the effect his own value system can have on the client.

Patterson goes on to explain:

By recognizing that the counselor's moral attitudes and values do enter into counseling, it prevents the counselor from erroneously believing that he is neutral. . . That is, he can freely be himself, without guilt about doing so, or without feeling that he should not have any feelings. . . While there are some who would sanction the counselor acting as a representative of society in prescribing moral or ethical values or standards, the majority of therapies, including client-centered therapy, st11l insist that the client must freely accept or reject such values, and develop or construct his own ethical system or philosophy of 1ife. 1

A survey of the literature reveals some exploration in the general area of the relationship of the counselor's value system to the counseling situation. However, no specific research has been attempted in the area regently undertaken.

1C. H. Patterson, Counseling and Psychotherapy: Theory and Bractice (New York: Harper and Brothers, 1959), pp. 73-74. 
THE PROCESS OF INVESTIGATION

This chapter is concerned with the methods used in the collection and analysis of the data which form the basis of this study. Attention is given to the collection of data by interviewing, the construction of the case study instrument, selection of a random sample, and the techniques employed in the analysis of the findings.

In order to complete a detailed research project in this area that will be somewhat valid, it has been necessary to narrow the field of study. Therefore, this study has dealt with but one element of a person's value system rather than the entire value system of the individual. This element was condemnation. The purpose of this investigation was to discover whether professionally certified teachers would be more likely to condem a student in a counseling situation than professionally certified guidance counselors.

Various methods of research could have been attempted in completing this project, including the administering of a mailed questionnaire, moral values test, and direct observation of counseling situations. However, there was a felt need that an interview type study be attempted in this area, since this approach seemed to be the most effective method to use in order to get beyond the surface of the problem.

Cannel1 and Kahn mention in discussing the interview as a method of collecting data that: "Attitudes, perceptions, expectations, anticipated 
behavior, are available to the economist, sociologist, psychologist, and thropologist only through such direct communication."1 They comment further: "Individuals' past experiences and future behavior are virtually unobtainable by other means."2 They conclude that "If the focal data for a research project are the attitudes and perceptions of individuals, the most direct and often the most fruitful approach is to ask the individuals themselves." "3

If the interview is to be a successful research device it must be administered with certain considerations in mind. In developing this study the following considerations have been adhered to: It seemed important not only to establish rapport but to maintain it throughout the interview. The respondent was assured that everything he said would be held in strict confidence. The interviewer attempted to help the interviewee understand that he was contributing to educational research and that the interview should be interesting to him. If the respondent should ask the question: "What are you really trying to find out?", the interviewer's answer would be: "We are doing research in the area of discipline and are trying to find the best way to handle this type of situation." When ending the interview, the interviewer still maintained rapport and tried to leave the respondent with a feeling that he had made a real

${ }^{1}$ Charles F. Cannell and Robert L. Kahn, "The Collection of Data by hterviewing," Research Methods in the Behavioral Sciences, ed. Leon Festinger and Daniel Katz (New York: The Dryden Press, 1953), p. 327.

2 Ibid., 331.

${ }^{3}$ Ibid., 330. 
contribution to society in the area of research on human behavior. Some sesponses were recorded in shorthand in order to insure the accuracy of the material revealed.

The research instrument that was developed for this study consisted of a case study, fifteen questions to structure the interviewees responses, and an information questionnaire to provide the additional relevant backcround information.

A great deal of effort was spent in developing a suitable pothetical case study to measure the feelings of condemation exhibited by teachers and guidance counselors. It was finally decided to use a case studyl which the interviewer personally observed. He has changed the school year (eighth grade to senior year of high school) and a few other minor details, but the essential features of the case remain the same. The interviewer prepared a number of questions ${ }^{2}$ to aid in the analysis of the information obtained from the use of the case study. After every question was asked, the interviewer emphasized the nondirective approach as much as possible in order to gain a deeper understanding of the respondent's real feelings. The questions were arranged so that they made the most sense to the respondent, while still allowing for a sequence that prevented early questions from conditioning the responses to later questions. Leading questions and loaded words were avoided in so far as possible.

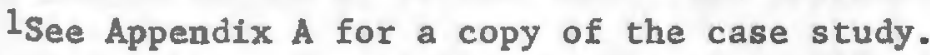

${ }^{2}$ See Appendix B for a copy of the questions. 
The information questionnaire ${ }^{1}$ was administered at the conclusion of each interview. It contained spaces for information on the respondent's Gakground, including educational level, work experience, years in teaching, and years in counseling. The results of this questionnaire are shown in Chapter Four in table form. Some implications may be drawn from the results of the information questionnaire, but it was used primarily as a tool to supply additional background information on the respondents.

A pilot study was completed on two teachers and two guidance eounselors on the staff of Joel Barlow High School in Redding, Connecticut. The people who participated thought that it was interesting to take, seemed to bring out their feelings about the problem, and yet did not embarrass them to any great degree. It appears that the case study and questions were simple to understand and accomplished the purpose of exposing feelings of condermation without giving away the reason for the research. Some minor adjustments and improvements were made in the case study, questions, and information questionnaire as a result of the pilot study.

Various methods of sampling could have been used in this study. It appeared that the results of the project might be somewhat invalidated by trying to indicate too much from a small sample if the selection of respondents were made according to an even distribution by sex (one-half men and one-half women); or by the subject matter the respondents presently teach or had taught before entering the field of full-time guidance and counseling.

A random sample of fifteen certified professional teachers from one high school faculty and a similar sample of certified professional guidance

'Isee Appendix c for a copy of the information questionnaire. 
counselors who were members of a county guidence association was made. It was felt that a random sample would be the most objective method, eliminating possible biased sampler selection.

Stephan and McCarthy illustrate the objectivity of the random sample:

When such a selection procedure as this is used, we say that every element in the population has an equal chance of being drawn into the sample and, furthermore, that each of the possible sets of elements of the required size has the same chance of being selected. 1

In order to clarify the terms used in this study the following definitions are presented:

Certification.--"Certification" is interpreted to mean the giving of professional recognition to people who possess certain minimal standards which meet the qualifications established by a legal certifying body. Teacher.--For the purpose of this study the term "teacher" is Interpreted to mean any person who is employed as a subject matter instructor at Joel Barlow High School in Redding, Connecticut and is certified by the State Department of Education in Connecticut to teach his subject matter area.

Counselor.--In this study the term "counselor" is interpreted to mean any person who is a member of the Fairfield County Personnel and Guidance Association, Fairfield, Connecticut, and is certified by the State Department of Education in Connecticut to act as a guidance counselor. Counseling.--For the purposes of this paper Tolbert's definition

lFrederick F. Stephan and Philip J. McCarthy, Sampling Opinions: Hnalysis of Survey Procedure (New York: John Wiley \& Sons, Inc., 8), p. 35 . 
of "counseling" will be used:

Counseling is a personal, face-to-face relationship between two people, in which the counselor, by means of the relationship and his special competencies, provides a learning situation in which the counselee, a normal sort of person, is helped to know himself and his present and possible future situations so that he can make use of his characteristics and potentialities in a way that is both satisfying to himself and beneficial to society, and further, can learn how to solve future problens and meet future needs. 1

Condemnation.--For the purposes of this study the term "condermation" is interpreted to mean that part of a person's value system that declares guilt, makes manifest the faults of an individual, sentences him to punishment, or censures the individual for possible moral wrongs.

Certain limitations in this study became apparent. These included:

(1) the small number of respondents that could be interviewed because of a lack of time, finances, and facilities, (2) the one geographic area of southern Connecticut which may or may not limit the implications of this study for other areas, and (3) the chance of bias by the interviewer and Interviewee in so subjective a situation as a personal interview. This could bring about a biased return.

Every possible precaution was used to minimize the effects of these limitations. In the final analysis, the need for this research seemed so necessary, that the limitations, though important, were not considered to be of such a restrictive nature as to invalidate the study. The limitations as well as the findings should provide a valuable basis for further study in this area, and the possible improvement of the techniques used.

1E. L. Tolbert, Introduction to Counseling (New York: McGraw-Hill Book Company, Inc., 1959), p. 3. 


\section{CHAPTER IV}

\section{THE RESULTS OF THE STUDY}

This chapter is concerned with presenting and discussing the results of the study. Each question asked in the interview is listed in the identical order that it appeared in the interview. Immediately following each question is an analysis of the responses to the question which were elicited from teachers and counselors during the research situation.

The information questionnaire was used primarily as a tool to auply background information on the respondents. Counselors that were Interviewed had an average age of forty-one, while teachers interviewed had an average age of thirty-four. Teachers had averaged 5.6 years of classroom teaching whereas counselors had averaged 10.1 years of classroom teaching before entering the field of counseling on a full-time basis. Guidance counselors averaged six years of experience in the field of counseling at the time they were interviewed. One counselor and one teacher had no other previous work experience outside of the field of education. It appears from the information gathered in the questionnaire that the guidance counselors were the more educationally mature group in this sample.

of the teachers interviewed, four had the most experience in teaching social studies, three had their greatest experience in teaching science, two in mathematics, two in English, and one each in physical 
education, home economics, industrial arts, and foreign languages. Six of the guidance counselors had taught primarily in the area of social studies before entering the field of full-time guidance. Two had taught primarily in the fields of mathematics, two in physical education, and two in business education. One each had taught primarily in the fields of science, Naglish, and industrial arts. The remaining information from the questionnaire appears below in table form:

\section{TABLE 1}

SEX, RELIGIOUS AFFILIATION, PRESENT EDUCATIONAL LEVEL, AND MARITAL STATUS OF THE TEACHERS AND COUNSELORS USED IN THE STUDY

\begin{tabular}{|c|c|c|c|c|c|c|c|c|}
\hline \multirow{2}{*}{$\begin{array}{l}\text { Random } \\
\text { Sample }\end{array}$} & \multicolumn{4}{|c|}{ Sex } & \multicolumn{4}{|c|}{ Marital Status } \\
\hline & \multicolumn{2}{|c|}{ Male } & \multicolumn{2}{|c|}{ Female } & Single & \multicolumn{3}{|c|}{ Married } \\
\hline Teachers & \multicolumn{2}{|c|}{7} & \multicolumn{2}{|c|}{8} & 2 & \multicolumn{3}{|c|}{13} \\
\hline Counselors & \multicolumn{2}{|c|}{11} & & 4 & 4 & \multicolumn{3}{|c|}{11} \\
\hline \multirow{2}{*}{$\begin{array}{l}\text { Random } \\
\text { Sample }\end{array}$} & \multicolumn{4}{|c|}{ Religious Affiliation } & \multicolumn{4}{|c|}{ Present Educational Level } \\
\hline & Protestant & & $\begin{array}{l}\text { Roman } \\
\text { atholic }\end{array}$ & Other & B.S. & M.S. & 6th Yr. & Dr. \\
\hline Teachers & 9 & & 6 & 0 & 6 & 7 & 2 & 0 \\
\hline Counselors & 8 & & 4 & 3 & 0 & 6 & 8 & 1 \\
\hline
\end{tabular}

Qeustion 1. "What do you think is your first obligation in this case?"

There appears to be very little variation between the responses given by teachers and counselors to this question. The question was dasigned to measure where a person's ultimate loyalty lies in a situation of this nature. Nine teachers said that they would feel their first loyalty was to the school and the principal, five teachers felt that their 
first loyalty lies with the student, and one teacher was undecided. Bight gidance counselors felt that their first loyalty rested with the school and principal and seven felt that the first responsibility was to the student. While the numerical differences were small, during the process of the interview it was observed that the counselors generally seemed to exhibit less fear of the school administration in their responses than did the teachers.

Question 2. "What possible alternatives are available to you in your attempt to handle this situation?"

This question was used to help the interviewee project his real feelings on how to best handle this case. Usually an interviewee mentioned a course of action as the one he would definitely use. Five teachers felt that they would try to discuss the matter with the student, four said that they would give the student a severe reprimand on the spot, five would take him to the principal immediately, and one teacher thought that it would be best to turn the matter over to the boy's guidance counselor. Six guidance counselors felt that they would like to discuss the matter with the boy, four felt that they would have to turn him into the principal immediately, two said that they would try to show him the error of his ways by giving him an immediate reprimand, two felt they would be obligated to turn the matter over to the boy's counselor, and one guidance person said it would be best to ignore what the boy was doing and to leave quietly. Question 3. "Do you think this boy. deserves disciplinary action? Why? Why not? If so, what kind?"

Most of the teachers and counselors interviewed felt that some disciplinary action was necessary in this case. Fourteen teachers and ten guidance counselors felt that some punishment should be given, while 
only one teacher and five counselors felt that the boy deserved no mpleasant consequences as a result of his action. The major reason given by the interviewees for disciplinary action was that the boy had violated gomeone's personal property. The punishment most often suggested was to prevent the boy from participating in some minor graduation activities. There was some fear expressed by many of the respondents that by not disciplining the boy the professional person might be condoning the act. Those people who voiced the opinion that the boy needed no disciplinary action seemed to feel that the boy was under tremendous pressure and that it was poor administrative policy to make anyone wait until just before graduation to find out if he were going to be a member of the graduating class.

Question 4. "What effect do you think such action, or lack of action will have on the other students?"

This question was not planned primarily as a source of information. It was intended to take emotional pressure away from the respondent, in other words to give him a breather. The question did have some information value. Seven teachers felt that the way they would handle the situation would bring about a negative response from the student body, while only three guidance counselors felt this way. Four teachers and six counselors thought that the student body would react in a pleased and positive way to the actions they had taken, four teachers and three counselors thought that there would be no reaction from the student body, and three counselors were undecided about the type of student action that would take place.

Question 5. "What type of person do you think this boy really is?" This was a projective type question where the respondent could give vent to his own emotional feelings about the boy. Most of the persons interviewed were quite anxious to give an opinion even though they had 
purposely been given very meager background information about the boy. Seven teachers and three counselors felt that the boy was lacking in moral fiber and character. Eight teachers and ten counselors seemed to feel that the boy was under a great deal of strain and pressure and that it was understandable that he yielded to the temptation of looking at the report cards. Two guidance counselors said that they could not make a decision unless they had more information.

Question 6. "What type of value system do you think this boy had?" This question was really a check on the responses that were given to question five. Ten teachers and six counselors thought that the boy had a very weak sense of right and wrong. No teachers and three counselors felt thet the boy could have had a very strong sense of right and wrong, but that he just yielded to the temptation that was presented to him. Four teachers and five counselors thought that he might have a stable but average value system. One teacher and one counselor felt that they didn't know enough about the boy to make a judgment.

Question 7. "How does this value system differ from your own?" Question number seven could indicate possible pious attitudes, ego protective devices, and feelings of understanding or condemation. Thirteen teachers and eight guidance counselors said that they would not have yielded to the temptation under the same circumstances. Most of the teachers were very strong in their immediate denial that they would do such a thing. However, many of the guidance counselors paused for a minute or two before denying that they would have been a party to such an action. Only two teachers. felt that they might have done the same thing as the boy if they had been under the same circumstances, whereas seven of the counselors felt that they might have done what the boy did. 
Question 8. "Should the principal be informed of this boy's bahavior?"

This question was a further check on the responses to question one which had to do with feelings of loyalty. Twelve teachers and eleven counselors said that the principal should be informed of the boy's behavior. An interesting point is that all of these people gave their answers enthusiastically. This course of action would be their only alternative. Most of the interviewees seemed to believe that it was a professional duty to inform the principal on this matter. One teacher and four counselors felt that they would not tell the principal. Two teachers qualified their statements by saying that if the principal were a "mean" individual they would not inform him, but if he were an understanding person, they would feel it their duty to divulge this information to him. Question 9. "Should the parents be informed of this boy's behavior?"

Question nine was designed to measure the seriousness of this situation in the eyes of the teachers and counselors. The teachers and counselors were somewhat divided on their responses to this question with ten teachers and only six counselors feeling that the parent's should be informed. Five teachers and nine counselors thought that this matter was not serious enough to warrant informing the parents.

Qeustion 10. "What should be the extent of the school's responsibility in dealing with a student like this boy?"

Although this question was included to serve primarily as a breather from the more personal questions in the interview, it did elicit some significant responses. Five teachers and three counselors thought that it was the school's primary responsibility to impress upon the youngster the wrongness of his action. Other suggestions were that the school could 
evaluate itself to see if it had been providing a satisfactory environment for its students, that it could try to follow this boy's future career to see if the school's treatment of this case had been successful, or that it could do nothing further at this late date.

Question 11. "What would you consider to be the advantages and/or disadvantages of your position in this situation?"

This question tried to indicate to a degree how the teachers and counselors defined their respective roles in this situation. The respondents could give as many advantages and disadvantages as they desired. Many teachers felt that their main advantages consisted of the previous training they had which would allow them to handle this situation in a professional way, the fact that the teacher's word would be respected by the administration, and that the teacher could expect the student to respect him. All teachers except one felt that the main disadvantage was the fact that the administration controlled the discipline function.

The guidance counselors seemed to feel that the advantages of their position were in being alone with the boy, being able to give the boy more understanding than he might otherwise receive, and being able to hold any information the boy divulged as confidential. The main disadvantages were that rapport might be lost with other students because of the punishment or reporting action the counselor might have to take in this situation, the counselor's sense of obligation to the school, and the ambivalent feelings about whether to use punishment and/or counseling in the treatment of this case.

Question 12. "What additional resources could you utilize other than those you could perform?"

This question was used to try to discover how the teachers and 
counselor felt about the capability of the school to handle this situation in its entirety. The teachers and counselors seem to be in agreement on this question; fourteen teachers and twelve counselors said that they would not consider using any additional resources outside of the school. This was the expected answer to the question. However, one teacher recommended that this event be brought to the attention of the boy's clergyman, two guidance counselors recommended psychological services if they were available, and one counselor would try to enroll the boy in a very active church youth group.

Question 13. "Would your actions differ in any way if this were a girl rather than aiboy involved in this case?"

Question thirteen was inserted to try to find out if teachers and counselors might be more shocked if a girl were discovered in this situation. Eleven teachers and thirteen counselors said that their actions would not differ in any way if this were a girl rather than a boy involved in this case. The only noticeable difference in their responses was that most teachers tended to give the answer emphatically and unhesitatingly, while the counselors tended to ponder over the question for a short period of time and their answers were generally given at a slower, more relaxed pace. Three teachers and two guidance counselors thought that they would be easier on the girl. However, one teacher thought that she would be harder on the girl.

Question 14. "Please react to this statement: 'There is no such thing as a bad boy." "I

This was an important question from a philosophical point of view. If it were answered with honesty, it could shed real light on a person's basic philosophy of life, especially in relation to his concepts concerning 
condemation and understanding as treatment devices. The responses to this question seem to strongly indicate that there is a major disagreement in basic philosophy here between teachers and counselors. Thirteen teachers disagreed with the basic assumption given in the question, while only two guidance counselors disagreed with it. Only two teachers agreed that there was no such thing as a bad boy, while thirteen counselors agreed with this concept. The responses to this question illustrated some conflicts in thinking between religious theories and sociological theories of behavior. Some of the respondents gave answers that tended to indicate they had done only shallow thinking about this philosophical concept.

It is interesting to note that eight out of the nine protestant teachers interviewed and three out of the four Roman Catholic teachers interviewed disagreed with the premise that there is no such thing as a bad boy. However, six out of the eight protestant counselors interviewed, and all four of the Roman Catholic counselors interviewed agreed that there was no such thing as a bad boy. This might tend to indicate that educational training and experience may have had a greater influence than religious background on the personalities of some of the people involved in this sample.

Question 15. "Is there anything you would like to add before we conclude the interview?"

Question fifteen was designed as a technique to end the interview and also to allow the respondent to make any comments or ask any questions which he felt were important. Most of the interviewees thought that the case study was interesting. They felt that the questions made them think, and helped them to analyze the case. Some specific questions that have 
more than a superficial import were: (1) Would my attitude have been any different if I had known the boy well? (2) If this case actually happened to the would I act on impulse and possibly react quite differently than I had indicated in the interview situation? 


\section{CHAPTER V}

\section{CONCLUSIONS AND RECOMMENDATIONS}

In keeping with the methods employed, a subjective evaluation rather than a statistical analysis was used in interpreting the results of the study. The responses of the interviewees, subjective in nature, suggested the following inferences:

1. Both teachers and counselors appeared to be sensitive to the authority image of the school administration. However, counselors seemed less fearful of the administration than did teachers during the interviews. This may be due to a guidance person's closer working association with the principal.

2. Teachers generally reacted in an authoritarian manner and counselors usually reacted in an understanding role. The teachers seemed much more interested in using discipline as a method of changing student behavior than did the guidance people. This may be due to the fact that counselors are usually trained to avoid disclpline in order to maintain rapport with a student, while teachers, of necessity, are taught to maintain control of their students. Most of the teachers and counselors interviewed seemed to respond in accordance with their expected professional roles.

3. The counselors were less likely than the teachers to consider the boy in the problem situation lacking in moral fiber and character. Counselors were more apt to look for the pressures that the subject had 
experienced, while the teachers generally considered him to be morally weak. There was a major disagreement between teachers and counselors concerning the classification of a person as good or bad. Almost all of the counselors felt that there was no such thing as a "bad boy", while all of the teachers except two felt strongly that a person was either "good" or "bad".

4. Guidance counselors appeared less ego protective than did the teachers during the interviews. Almost one-half of the counselors interviewed felt that they might have looked at the report cards themselves if they were in the boy's situation, whereas all of the teachers except two felt that they would not have yielded to the terptation under the same circumstances. Most of the teachers were very strong in their immediate denial that they would do such a thing. The counselors who felt that they would not look at the report cards usually paused for a few minutes to consider whether or not this would actually be the case.

5. The differences in attitudes exhibited by teachers and counselors during the interviews may be partially explained by their respective personality makeups and the type of training that each role requires for certification. The respective religious backgrounds of the respondents did not appear to be highly related to the attitudes held. Counselors may have somewhat different personality traits than teachers which could have attracted them to the counselor's role. Graduate training in guidance and counseling may have an effect on changing the counselor's value system. It is also possible that his value system is not changed to any large degree, but that the training may enable the counselor to cover up his real feelings while he is acting out his professional role. Consistent with the general findings and conclusions of this study the following two recommendations can be reasonably made: 
1. Departments of education should devise appropriate means for assessing, through counseling, the personality characteristics of potential teachers and counselors at an early stage in their undergraduate preparation. It would be of considerable assistance to the college student in helping him understand his reasons for wanting to become a teacher or counselor. Such a counseling program would contribute to the mental health atmosphere of our elementary and secondary schools, by screening out persons with potentially damaging personality patterns. A teacher's personality would appear to be as important to his students as his knowledge of subject matter. It is even more important that counselors be emotionally stable because of the individual face-to-face relationships involved. 2. With reference to the following critical questions, it is important that answers be found regarding the development of the value systems of the professional teacher and counselor. How does his value system affect his relationship with students? Can the value system be changed to any great degree? Do professional courses in counseling techniques contribute substantially to the development of such value systems?

Educators are profoundly concerned about the role identification of teachers and counselors. The counselor in the decades ahead will require a finer definition of his role in the total educational scene. Better methods of selecting future teachers and counselors must be developed if a positive program of mental health is to be realized in our schools. More attention must be paid to the development of value systems within professional persons and to the effects of these value systems upon counseling relationships. 


\section{APPENDIX A \\ THE CASE STUDY INSTRUMENT}

Please put yourself in this position. You, as a (teacher) (counselor) are on your way to the principal's office to discuss a routine matter with him. As you begin to enter his office you notice that a student, Jim $X$, is the only person in the office. He is opening the right hand top drawer of the principal's desk. Jim pulls out a stack of report cards, quickly thumbs through them to find his own, opens it quickly and glances at it. He then quickly surveys two or three other cards, as he restacks the pile presumably to put them away. While restacking the report cards he turns and notices you standing there.

This entire experience takes place within thirty seconds.

ADDITIONAL BACKGROUND: You have never had any contact with Jim previous to this time. You have, however, been exposed to the following facts through faculty conversations and bulletins from the administration:

1. All seniors have completed final exams and the grades have been recorded on the report cards.

2. It has also been indicated on each report card whether a student has or has not qualified for graduation.

3. The graduation list will be posted on the main bulletin board three days from today.

4. Jim has been a borderline student and there is some doubt as to whether he will graduate.

5. Jim's particular peer group, three close buddies, are also uncertain about graduation.

How would you, as a (teacher) (counselor) handle this situation? 


\section{APPENDIX B}

\section{THE INTERVIEW QUESTIONS}

1. What do you think is your first obligation in this case?

2. What possible alternatives are available to you in your attempt to handle this situation?

3. Do you think this boy deserves disciplinary action? Why? Why not? If so, what kind?

4. What effect do you think such action or lack of action will have on the other students?

5. What type of person do you think this boy really is?

6. What type of value system do you think this boy had?

7. How does this value system differ from your own?

8. Should the principal be informed of this boy's behavior?

9. Should the parents be informed of this boy's behavior?

10. What should be the extent of the school's responsibility in dealing with a student like this boy?

11. What would you consider to be the advantages and/or disadvantages of your position in this situation?

12. What additional resources could you utilize other than those you could perform?

13. Would your actions differ in any way if this were a girl rather than a boy involved in this case?

14. Please react to this statement: "There is no such thing as a bad boy."

15. Is there anything you would like to add before we conclude the interview? 
APPENDIX C

THE INFORMATION QUESTIONNAIRE

NAME :

Last First Middle

DATE OF BIRTH:

Month Day Year

CODE NO. TOWN:

ADDRESS :

RELIGIOUS AFFILIATION: SEX: Male or Female

(please circle one): SINGLE, MARRIED, DIVORCED, WIDOWHOOD

EDUCATION: (please circle highest degree attained) BACHELOR'S MASTER'S SIXTH YEAR DOCTOR'S

WORK EXPERIENCE: $1 . \longrightarrow 2$. SUBJECT YOU HAVE TAUGHT THE MOST: 


\section{BIBTIOGAPHY}

\section{Books}

Abrahamsen, David. Crime and the Human Mind. Ner York: Columbia University Press, 194.4 .

Anderson, Camilla M. Saints, Sinners and Psychiatry. Philadelphia: J. B. Lippincott Company, 1950 .

Angell, Robert Cooley. Free Society and Moral Crisis. Ann Arbor: The University of Michigan Press, 1950.

Derger, Horroe, Abel, Theodore, and Page, Charles. Ereedom and Control in Modern Society. Wew York: D. Van Wostrand Company, Inc, 1954 .

Bloch, Herbert A. Disorganization: Bersonal ana Jocial. liew York: Alfred A. Knope, 1952.

Broon, Leonard, and Selznick, Philip. Sociology: A Pext with Adapted Readings. White Plains, New York: Row, retexson, and Company, 1955.

3rown, L. Guy. Social Pathology: Personal anc Bocial Disorganization. itew York: F. S. Crofts and Company, 1946.

Cannel1, Charles $F .$, and Kahn, Robert L. "The Collection of Data by Interviewing," Research ilethods in the Behavioral sciences. ed. Leon Festinger and Daniel Ratz. Mav Yorl: The Dryden Fress, 1953.

Dahlke, H. Otto. Values in Culture and Classyoom. Tev York: Harper i Brothers, 1950 .

Javis, Allison, and Havighurst, Robert J. Father of the Lan: How Your Child Gats isis Personality. Soston: Houghton Mifflin Corpany, 1947.

Devey, John. Human Nature and Conduct. Hev York: Weny rult and Company, 1922 .

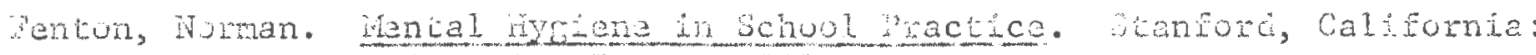
Stanford University press, 1962. 
Fromn-keichman, Frieda. Ininciples of Intensive Isychotherapy. Chicago: The University of Chicaso Iress, 1950.

Gjllin, John L., and Gillin, Join 2. An Introduction to Sociology. New York: The Yacuillan Company, 1946.

yman, Lerbart h. Intervieving in Social Research. Chtcago: the University of Chicaro Press, 1954.

Johnson, Zdgar J., Peters, liflered, and Guriaff, wilian. the Role of the Teacher in Guidance. Inglewood Cliffs, Wew Jersey: PrenticeHal1, Inc., 1959.

Tandis, Paul H. Social Control: Social urganization and jisorganization in Process. New York: J. B. Lippincott Company, 1956.

Lundberg, George A. Soctal jesearch: A study in Wethods of Gathering Data. Naw York: Congmans, Green, aná Company, 1948.

Wathawson, Nobert Hendry. Gudance Policy and Practice. New York: Harper and Brothers, 1949.

Worse, Wiliam G. and Wngo, Sax. Psycholojy and Seching. Wew York: Scott, Foresman and Company, 1955.

Mplar, Harvin K. Culture, Psychiatxy, and Human Values. SpringEield, Illinois: Bannerstone Kouse, 1950.

vaterson, C. $\mathrm{A}$. Counseing and Jsychotherapy: Theory and Practice. New York: Harper and Brothers, 1959.

Nogars, Carl R. Client-Centered Tharapy. ivew York: houghton bifflin Curapany, 1951.

Wesch, Jurgen and Bateson, Gregry. Commicton: Whe 3pcial hatrix

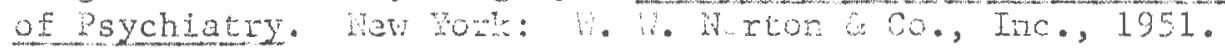

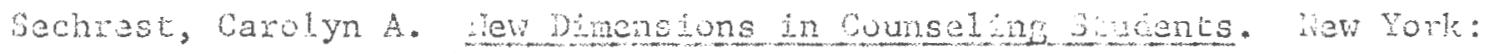
Bureau of lubloctons, eachers College, Cumbie University, 1958.

Shostrom, Everett $I$. The Dynanics of the Somsel ng Process. New York: lc graw-Fill Buok o., Inc., 1952.

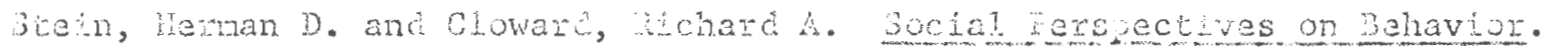
Glencoe, ill: rhe ras mess ablishers, 1958.

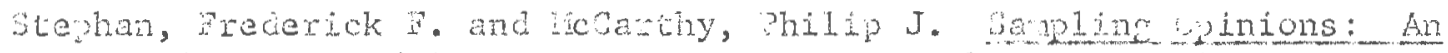

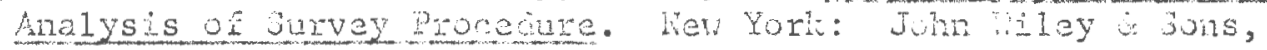
Inc., 1953.

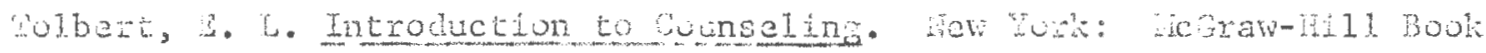
Company, Inc., 1959. 
Varters, Jane. Techniques of Counseling. Naw York: MoGraw-Hill Book Company, Inc., 1954.

roung, rimball. Social 2sycholosy. New pork: 2 . S. Crofts and Co., Inc., 1947.

\section{Articles and Periodicals}

Biestek, F. P. "The Non-Judgmental Attitude," jocial basework, XKXIV (June, 1953), 235-239.

Sosentha1, David. "Changes in Sone Moral Valuas Following Psychutherapy," Journal of Consulting. Esychology, Vol. 19 (Decenber, 1955), 431-436.

$3 \operatorname{tanlay,~Julian~C.~"Insight~Into~Une's~Own~Values,"~The~Journal~of~}$ Educational Psychology, Vol. 42 (November, 1951), 399-408.

Williamson, 3anund G. "Value Orientation in Counseling," The Personnal and Guidance Journal, XaXVI (April, 1953), 521.

\section{Unpublished Material}

Arickson, Allan C. "An Investigation of the Ralationship of Social Characteristics to Responses from Selected Hichigan High school Counselors." Unpublished fd. D. dissertation, School of Graduate Studies, Michigan State College, 1954.

Watch, Eith Viola. The Counseling Interview in Twenty-Two public High Schools in Rhode Island." Unpublished Master's thesis, Department of Rducation, University of Rhode Island, 1957.

\section{Uther Sources}

- Personal interview with Allan C. Arickson, Professor of Education. February 12, 1960. 